\section{Phagocytosis of Salmonellae by Reticulo- endothelial Cells of New-born Piglets lacking Natural Antibody}

Ir is a well-established fact that the uptake of bacteria by phagocytes is enhanced by serum factors (opsonins) acting on bacterial surface. Tho importance of serum opsonins in the phagocytosis of bacteria by fixed macrophages of the reticulo-endothelial system has beon demonstrated by organ perfusion technique. It has been shown that serum factors playing a part in bacterial opsonization include immune or natural antibody, com. plement and possibly a third unidentified factor ${ }^{1,2}$.
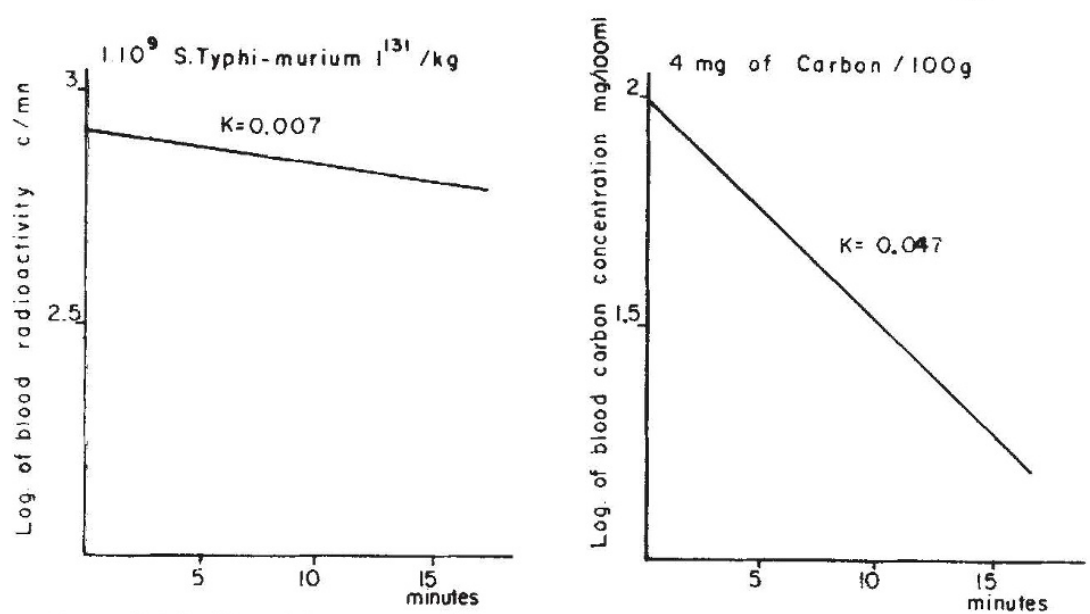

Organ distribution of Solmonellae I $^{3 \mid}$

$\begin{array}{lrc} & c / m i n / 9 & \begin{array}{c}\text { per cent of } \\ \text { injected radioacfivity }\end{array} \\ \text { Liver } & 1,000 & 17 \\ \text { Spleen } & 80,000 & 44 \\ \text { Lungs } & 1,200 & 10 \\ \text { Kidneys } & 150 & 0.7 \\ \text { Blood } & & 10 \\ & & \frac{81.7 \text { (total) }}{}\end{array}$

$\begin{array}{lcc}\begin{array}{c}\text { Organ distribution of Carbon } \\ \mathrm{mg} / \mathrm{g}\end{array} & \begin{array}{c}\text { per cent of } \\ \text { the injected dose }\end{array} \\ \text { Liver } & 1.1 & 75 \\ \text { Spleen } & 4.8 & 12 \\ \text { Lungs } & - & \text { traces } \\ \text { Kidneys } & - & \frac{\text { troces }}{87 \text { (total) }}\end{array}$

Fig. 1. liate of blood clearance $(K)$ and organs distribution of $S$ typhimurium labelled with iodine-131 and colloidal cerbon in new-born piglets. The figures represent the mean value of three animals. The $K$ value is detcrmined by the formula: $K=\frac{\log C t-\log C t^{\prime}}{C,}$, blood concentration; $t$, time expressed in min

The use of radiolabelled bacteria has made possible quantitative measurement of opsonins in the phagocytosis of bacteria by the reticulo-endothelial system in vivo ${ }^{3-5}$. The importance of antibody and complement in the phenomenon of bacterial opsonization has therefore been demonstrated in the intact animal ${ }^{6,7}$. It has also beon suggested that the rate of phagocytosis of bacteria in different animal species was related to the amount of natural antibodies present in thoir serum ${ }^{8}$. In germ-free mice which are supposed to contain a lower amount of natural antibodies, the blood clearance of $E$. coli is slightly decreased. Nevertheless the bacterial repartition in the phagocytes of liver and spleen is similar in germ-free and control mice ${ }^{8}$.

Recently, Sterzl et al. have shown that scrum from new-born piglets deprived of colostrum was totally lacking in natural antibodies but contained $1-3$ units of compleinent per $\mathrm{ml}^{9}$. Now-born piglets offer, therefore, an $\theta \mathrm{x}$. ceptional opportunity to investigate whether phagocytosis of bacteria by reticulo-endothelial cells in vivo occurs even in the absence of natural antibodies.

Investigation of phagocytosis of $S$. typhimurium by the reticulo-endothelial system in new-born piglets deprived of colostrum are reported here. These experiments were performed in fasting piglets $3-5 \mathrm{~h}$ after birth. The smooth phase of S. typhimurium $34 / 59$ trace labelled with iodine-131 (ref. 4) was injected in an ear vein The rate of blood clear- ance of labelled bacteria was established by measuring the radioactivity of blood samples removed from the opposit ear vein. When about 90 per cent of the radioactive bacteria were cleared from the blood the animals were killed and the radioactivity of different organs determined.

In another group of piglets the phagocytic activity of the reticulo-endothelial system was established by measuring the blood clearance and organ distribution of intravenously injected colloidal carbon using a technique: previously described ${ }^{10}$.

The results obtained in these experiments are sum. marized in Fig. 1.

It appoars that Salmonellae are removed very slowly from the blood with a $K$ value of 0.007 . The distribution of the radioactivity in the organs shows that the majority of the. bacteria are fixed in the spleen. The spleen, which weighed only about $1 \mathrm{~g}$. accumulated 44 per cent of the injected bacteria while the whole liver (about $33 \mathrm{~g}$ ) contained only 17 per cont. The number of bacteria per g of tissue was 80 times higher in the spleon than in the liver and this latter organ contained about the same amount of radioactivity as the lungs. It is important to note that the organ distribution of Salmonellae was very different in adult animals containing natural or immuno antibodies. In adult animals the liver fixed $50-80$ per cent and the spleen 5-25 per cent of the injected number of bacteria ${ }^{3,4,7}$.

Examination of the phagosytic activity of the reticulo-endothelial cells with colloidal carbon in new-born piglets shows that the lack of bacterial fixation in the liver is not due to the inefficiency of the phagocytic function of the Kupffer's cells in the early stage. of life, since these cells phagocytize $7 \%$ per cent of the injected amount of carbon. The phagocytic index $K$ and the carbon distribution in the organs of newborn piglets are similar to those of adult animals ${ }^{11}$. Sterzl et al. have also shown that the reticulo-endothelial cells of newborn piglets deprived of colostrum phagocytize carbon particles at the same rate as piglets fed with colostrum ${ }^{12}$.

These results indicate that, in new-born piglets, the absonce of natural antibody inhibits the uptake of bacteria by Kupffer's cells, while the phagocytes of the spleen are capable of vigorous phagocytosis. It is interesting to emphasize the striking difference in tho part playod by opsonins in phagocytosis of bacteria by the Kupffer's cells and by the reticulo-endothelial cells of the sploon.

\section{Mouton \\ G. Biozzi \\ Y. BOUTHIMLLER \\ C. Stiffeit.}

Centre de Recherches allergiques et immunologiques, Hôpital Broussais, 96 rue Didot, Paris 14.

'Manwaring, W. H., and Fritschen, W., J. Immunol., 8, 83 (1923).
' Howard, J. G., and Wardlaw, A, C., Immunology, 1, 338 (1958).

senacerraf, B., Sebestyen, M. M., and Schlossman, S., J. Exp. Med., 110 $27(1959)$.

Biozzi, G., Howard, J. G., Halpern, 13. N., Stiffel, C., and Mouton, D. Immunology, 3, 74 (1960).

Biozzi, G., Stiffel, C., Halpern, B. N., Le Yinor, L., and Mouton, 1). J.Immunol., 87, 296 (1961)

Genacerraf, B, and Miéscher, P., Ann. N.Y. Acad. Sci., 88, 184 (1960).

- Biozzi, G., and Stiffel, C., Mechanism of Cell and Tissue Damage produrpe by Immune Reactions, '249 (Benno Schwabe and Co., Basle, 1962).

Thorbecke, G. J., and Benacerraf, B., Ann. N.Y, Acad. Sci., 78, 247 (1959).

- Sterzl, J., Kostka, J, and Liane, A., Fol. Microbiol., 7, 162 (1982).

10 Biozzi, G., Benacerraf, B., and Halpern, B. N., Brit. J. Exp. Path., 34 441 (1953).

"1. Benacerraf, B., Biozzi, G., Halpern, B. N., and Stiffel, C., Physiopatholog"

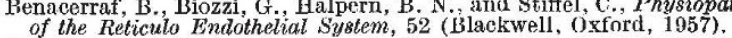

sterzl, J., and Trnka, Z., Giornale di Malattie infettive e Parassitarie. 2. (1959) 